\title{
The effects of probiotic Bacillus subtilis on the cytotoxicity of Clostridium perfringens type a in Caco-2 cell culture
}

\author{
Maryam Poormontaseri ${ }^{1}$, Saeid Hosseinzadeh ${ }^{1 *}$, Seyed Shahram Shekarforoush ${ }^{1}$ and Tahereh Kalantari ${ }^{2}$
}

\begin{abstract}
Background: Some Bacillus strains have recently been identified for potential use as probiotics and food additives. The present study evaluated the antimicrobial effects of Bacillus subtilis ATCC 6633 and its metabolite on the enterotoxin and vegetative cells, spore and germinated spore of Clostridium perfringens type A in Caco-2 cells.

Results: We used flow cytometry and MTT assays to evaluate the cytotoxicity effect of treatments. According to the results, the most cell survival was found in the $4 \%$ crude antimicrobial substance (CAS) with the vegetative form of $C$. perfringens among co-cultured groups. Furthermore, the apoptosis and necrosis in co-cultured groups were significantly decreased $(P<0.05)$.

Conclusion: The present results suggested the crucial role of the current probiotic in the control of various forms of $C$. perfringens type A which was investigated for the first time. Also, the majority of treatments showed higher cell viability in flow cytometry compared to the MTT assay.
\end{abstract}

Keywords: Bacillus Subtilis, Clostridium perfringens, Cytotoxicity, Flow cytometry, Caco-2 cell line

\section{Background}

Clostridium perfringens type A is the second most common cause of food poisoning in the world, and the third most common in the USA. The major virulence factor of $C$. perfringens is enterotoxin (CPE), a $35 \mathrm{kDa}$ single polypeptide which causes diarrhea and abdominal cramps upon release in the host gut. CPE is a potent cytotoxic agent which acts by permeabilising enterocyte cell membranes such as Caco-2 cells by binding to claudin receptors on the apical surfaces [1].

One potential way to combat enteropathogens is through probiotics. Probiotics are microorganisms which improve humans' and animals' intestinal microbial balance via consumption of adequate amount of them $\left(10^{8}-10^{12} \mathrm{CFU} /\right.$ day based on type of the bacteria) [2,3]. Bacillus probiotics and their metabolites are promising candidates in biotechnological applications and in the fermented foods [4]. Compared with common probiotics species such as Lactobacillus and Bifidobacterium, Bacillus are highly

\footnotetext{
* Correspondence: hosseinzadeh@shirazu.ac.ir

1 Department of Food Hygiene and Public Health, School of Veterinary

Medicine, Shiraz University, P.O. Box: 71441-69155, Shiraz, Iran

Full list of author information is available at the end of the article
}

heat and chemical resistant are capable of surviving harsh gastric fluid $\mathrm{pH}$ due to spore forming, making them ideal as food additives for human and animal use [5]. Other beneficial effects of B. subtilis include production of enzymes, amino acids and antibiotic compounds such as bacteriocins and improving gut-associated lymphoid tissue (GALT) in human and animals [6, 7]. It has been previously revealed that B. subtilis ATCC 6633 had inhibitory effect against Gram positive and Gram negative enteropathogens via production of subtilosin A bacteriocin, in an in vitro model [7]. Furthermore, B. subtilis probiotics are capable of adhering the gut cells, thereby combatting enteropathogens by a competitive exclusion mechanism [7-9].

Epithelial cell monolayers such as Caco-2 and HT-29 cell lines, are well established as in vitro simulations of the gut ecosystem. These cultures are effective tools for modelling pathogen colonization and cytotoxicity in the gut, as well as studying the antibacterial effects of probiotics [10]. The present in vitro study was conducted to evaluate the antibacterial effects of B. subtilis ATCC 6633 on the enterotoxin, vegetative cells, spores and germinated spores of C. perfringens type A. 


\section{Methods}

\section{Bacterial strains and culture conditions}

Bacillus subtilis subsp. spizizenii ATCC 6633 and Clostridium perfringens type A (NCTC 8239) was purchased from the Iranian Organizations for Science and Technology (Tehran, Iran). B. subtilis was aerobically cultured in TSB broth (Merck, Germany) supplemented with $1 \%(w / v)$ yeast extract (Merck, Germany) (TSBYE) for $18 \mathrm{~h}$ at $37{ }^{\circ} \mathrm{C}$. C. perfringens was anaerobically cultured in thioglycolate broth (Merck, Germany) for $18 \mathrm{~h}$ at $37{ }^{\circ} \mathrm{C}$. Both were then centrifuged $(3000 \times \mathrm{g}, 10 \mathrm{~min})$ and washed using sterile phosphate-buffer saline (PBS, pH 7.4). A final concentration of $10^{7} \mathrm{CFU} / \mathrm{mL}$ was re-suspended in cell culture medium for further assays.

\section{Preparation of spore, germinated spore and CPE of $C$. perfringens}

To prepare CPE, $500 \mathrm{~mL}$ overnight bacterial culture in thioglycolate broth $(\mathrm{pH}$ 7.1) was seeded into $4.5 \mathrm{~L}$ Duncan-Strong sporulation medium, which was in turn incubated anaerobically at $37{ }^{\circ} \mathrm{C}$ for $8 \mathrm{~h}$. The prepared sporangium was then sonicated ( $2 \mathrm{~min} / 5 \mathrm{~min}$ intervals) (Fungilab, Spain). The suspension was centrifuged at $10000 \times \mathrm{g}$ for $30 \mathrm{~min}$ at $4{ }^{\circ} \mathrm{C}$ and the supernatant containing $\mathrm{CPE}$ was stored at $-20{ }^{\circ} \mathrm{C}$ for SDS-polyacrylamide gel electrophoresis (SDS-PAGE) analysis. The pellet containing spores was then washed using distilled water (DW), and suspended in $20 \mathrm{~mL} \mathrm{DW}$ before being stored at $4{ }^{\circ} \mathrm{C}$. To enumerate the spores, the suspension was heated at $75{ }^{\circ} \mathrm{C}$ for 20 min, 10 fold serially diluted and subcultured onto Brain Heart Infusion (BHI) agar (Merck, Germany) and incubated anaerobically at $37^{\circ} \mathrm{C}$ for $24 \mathrm{~h}[11,12]$.

To vegetate spores, the spore suspension was heat activated at $75{ }^{\circ} \mathrm{C}$ for $20 \mathrm{~min}$ and subsequently incubated at $30{ }^{\circ} \mathrm{C}$ for $10 \mathrm{~min}[13]$.

\section{Approximate quantification of CPE and SDS-PAGE assay} To precipitate CPE, the same volume of $40 \%$ ammonium sulfate was added to the supernatant, left overnight at $4{ }^{\circ} \mathrm{C}$, centrifuged at $10000 \times \mathrm{g} / 30 \mathrm{~min} / 4{ }^{\circ} \mathrm{C}$, dissolved in $0.02 \mathrm{M}$ PBS and finally subjected to chromatography. Gel filtration chromatography was performed on a Sephadex G-200 gel $(2 \mathrm{~cm} \times 90 \mathrm{~cm})$ in $0.02 \mathrm{M}$ phosphate running buffer to partially purify the CPE. The flow rate was $20 \mathrm{~mL} / \mathrm{h}$ and $3 \mathrm{~mL}$ fraction was collected [12-14]. Bradford assay was respectively employed to quantify the product. $100 \mu \mathrm{L}$ of the preparation was initially mixed with $1 \mathrm{~mL}$ Bradford dye, optical density (OD) was recorded at $595 \mathrm{~nm}$ and the final concentration $(\mathrm{mg} / \mathrm{mL})$ was reported [15].

CPE molecular weight was then determined by SDSPAGE based on the method described by Laemmli (1970). The CPE sample was mixed with sample buffer $(62.5 \mathrm{mM}$ Tris- $\mathrm{HCl}, 10 \%(v / v)$ glycerol, 2\% $(w / v)$ SDS, 5\% ( $/ / \mathrm{v})$,
B-mercaptoethanol, and $0.125 \%(w / v)$ bromphenol blue, $\mathrm{pH}$ 6.8) and heated at $95{ }^{\circ} \mathrm{C}$ for $5 \mathrm{~min}$ [13].

\section{Preparation of antimicrobial substance}

To extract the antimicrobial substance from B. subtilis ATCC 6633, the cell free supernatant was initially prepared by propagating the bacteria in TSBYE for $18 \mathrm{~h}$ at $37{ }^{\circ} \mathrm{C}$, then centrifuged $\left(7000 \times \mathrm{g}, 20 \mathrm{~min}, 4^{\circ} \mathrm{C}\right)$ to provide crude antimicrobial substance (CAS). The supernatant was then collected and freeze dried. Various concentrations of CAS were dissolved in RPMI medium and adjusted to $\mathrm{pH} 7$ (recorded by $\mathrm{pH}$ meter BASIC 20, Cerison, UK). Hydrogen peroxide was removed from the CAS using catalase enzyme (Sigma-Aldrich, USA), after which the sample was filter sterilized. CAS protein concentration was determined by the Bradford method as described [15].

\section{Minimal inhibitory concentration (MIC) assay of CAS}

$8 \%$ B. subtilis CAS was prepared in TSB. $100 \mu \mathrm{L}$ of the solution was then added to each well of a 96-well microtiter plate and $10 \mu \mathrm{l}$ of the bacteria, spore and germinated spore suspensions were added to each well and incubated anaerobically at $37^{\circ} \mathrm{C}$ for $24 \mathrm{~h}$. Growth was determined by measuring the OD of each well at $600 \mathrm{~nm}$ using a micro well plate reader (BioTek, USA). MIC was confirmed at the lowest dilution of CAS without significant growth above the original inoculum $(P<0.05)$. The test was repeated in triplicate. Percentage inhibition of bacterial growth was determined using the following equation: [(OD positive control (between $0 \mathrm{~h}$ to $24 \mathrm{~h}$ ) - OD sample (between $0 \mathrm{~h}$ to $24 \mathrm{~h}$ ))/OD positive control (between $0 \mathrm{~h}$ to $24 \mathrm{~h})] \times 100$ [16].

\section{Cell culture}

Caco-2 ATCC HTB-37 was provided by the Pasteur Institute of Iran (Tehran, Iran). Cells were grown in RPMI 1640 (BioIdea, Iran) supplemented with 20\% fetal bovine serum (FBS) (Gibco, USA), 1\% ( $\mathrm{v} / \mathrm{v})$ penicillin-streptomycin antibiotic $(10,000 \mathrm{IU} / \mathrm{mL}$ and $10,000 \mu \mathrm{g} / \mathrm{mL}$, respectively; Bioldea, Iran) and amphotericin B (50 mg/10 mL) (Sigma, USA). The Cells were incubated at $37{ }^{\circ} \mathrm{C}$ in $5 \% \mathrm{CO}_{2}$. For subsequent assays, cell monolayers were prepared in 96well tissue culture plates by seeding $3 \times 10^{4}$ cells/well and incubated for $48 \mathrm{~h}$ to reach confluence. In Caco- 2 cells, experiments were carried out after cells were differentiated (15 days post-confluence) [17].

\section{Cytotoxic effect of $B$. subtilis and $C$. perfringens}

The cytotoxicity test was performed as previously described [18]. Briefly, the cell monolayers were first washed using PBS, and $100 \mu \mathrm{L}$ RPMI media (not supplemented) was added to each well and incubated at $37{ }^{\circ} \mathrm{C}$ in $5 \% \mathrm{CO}_{2}$ for $1 \mathrm{~h}$. Cells were infected with $100 \mu \mathrm{L} /$ well B. subtilis, CAS $(4 \%, 8 \%)$, vegetative bacteria, spore and germinated spore of 
C. perfringens suspensions $\left(10^{7} \mathrm{CFU} / \mathrm{mL} \mathrm{RPMI}\right)$ and then incubated at $37{ }^{\circ} \mathrm{C}$ for $18 \mathrm{~h}$ in $5 \% \mathrm{CO}_{2}$. Monolayers in the growth media were used as negative controls. Cellular metabolic activity assays of epithelial cells were conducted using 3-(4,5 dimethylthiazol-2-yl)-2,5-diphenyl tetrazolium bromide (MTT) kit (Bioldea, Iran).

After the incubation period, the growth medium was replaced by $100 \mu \mathrm{L}$ RPMI 1640 (RPMI 1640 without phenol red), $10 \mu \mathrm{L} 12 \mathrm{mM}$ MTT solution was added to each well, plates were incubated at $37^{\circ} \mathrm{C}$ for $4 \mathrm{~h}$ and the medium was replaced with $50 \mu$ l Dimethyl sulfoxide (DMSO). The plates were then incubated at $37{ }^{\circ} \mathrm{C}$ for $10 \mathrm{~min}$ and the absorbance of wells were measured at $570 \mathrm{~nm}$ using a microplate reader (BioTek, USA). Toxicity was calculated using the eq. [1-(OD test sample/ OD negative control)] x 100 [18].

\section{Cytotoxic effect of co-cultured B. subtilis and C. perfringens on Caco-2 cells}

$100 \mu \mathrm{L}$ B. subtilis $\left(10^{7} \mathrm{CFU} / \mathrm{mL}\right)$ was added to washed monolayers, which were then incubated in $5 \% \mathrm{CO}_{2}$ at $37^{\circ} \mathrm{C}$ for $1 \mathrm{~h} .10^{7} \mathrm{CFU} / \mathrm{mL}$ of either vegetative bacterium, spore or germinated spore forms of $C$. perfringens and CPE $(2 \mu \mathrm{g} / \mathrm{mL})$ were then added to each well. Three wells, each of positive and negative control were also included. The microplate was then incubated in $5 \% \mathrm{CO}_{2}$ at $37{ }^{\circ} \mathrm{C}$ for $1 \mathrm{~h}$. Monolayers were then washed in sterile PBS before the MTT assay was carried out [19].

\section{Survival rates, early apoptosis and necrosis of treated Caco-2 cells}

All treatments used in MTT assays were subjected to flow cytometry. Monolayers were incubated with $B$. subtilis probiotic $\left(10^{7} \mathrm{CFU} / \mathrm{mL}\right)$ in T-12.5 flasks. $10^{7} \mathrm{CFU} / \mathrm{mL}$ each vegetative bacterium, spore and germinated spore forms of C. perfringens and CPE $(2 \mu \mathrm{g} / \mathrm{mL})$ were added to flasks containing either B. subtilis $\left(10^{7} \mathrm{CFU} / \mathrm{mL}\right)$ or CAS $(8 \%)$. Two flasks of negative (cells suspended in binding buffer $1 \times$ ) and positive controls (cells added to paraformaldehyde then binding buffer) were also prepared. Cells were then trypsinized and centrifuged at $200 \times \mathrm{g}$, for $8 \mathrm{~min}$. Supernatants were discarded and the cell suspensions were washed three times using PBS. After the final wash, supernatants were replaced by binding buffer $1 \times$ and transferred to $1.5 \mathrm{~mL}$ microtubes. Positive, negative and unstained controls were prepared according to the PE Annexin V Apoptosis Detection Kit I (BD Biosciences, US). For each cell experiment run, data for 100,000 events was determined by flow cytometry (BD FACSCalibur, USA) [20]. The data were then analysed using FlowJo software.

\section{Statistical analysis}

The data were analysed using SPSS (version 16.0) software (SPSS, Inc., Chicago, IL) and subjected to one-way ANOVA test. The difference of means between the groups was also analysed using Duncan post-test. Level of statistical significance was $P<0.05$. Flow cytometry data were also analysed by FlowJo (version 7.6) software (Flexera, US).

\section{Results}

\section{Purification of CPE by SDS-PAGE}

According to the protein standard curve equation of the Bradford assay $\left(y=91.822 \times-20.975, r^{2}=0.982\right)$, a concentration of $470 \mu \mathrm{g} / \mathrm{mL}$ CPE was yielded by gel filtration chromatography. SDS-PAGE (10\% gel) was also run to determine the corresponding molecular weight of CPE (Fig. 1).

\section{MIC assay of CAS}

The MIC of CAS $(4 \%, 8 \%)$ against the vegetative form of $C$. perfringens was assessed using the microdilution method. 8\% CAS inhibited the growth of vegetative cells, germinated spore and spore of $C$. perfringens at the MIC of $76.12 \pm 8.13 \%, 74.04 \pm 5.99 \%$ and $54.72 \pm 3.81 \%$, respectively. At $4 \%$ CAS, MIC was $51.34 \pm 5.67 \%, 57.63 \pm 8.19$ and $43.42 \pm 3.39 \%$ respectively (Fig. 2). A significant difference between the vegetative bacteria, germinated spore and spore was shown in both groups.

\section{Cytotoxic effect of B. subtilis and C. perfringens on Caco-2 cells}

The cytotoxicity of B. subtilis, CAS (8\%, 4\%), CPE $(1 \mu \mathrm{g} / \mathrm{mL})$ and different forms of $C$. perfringens were

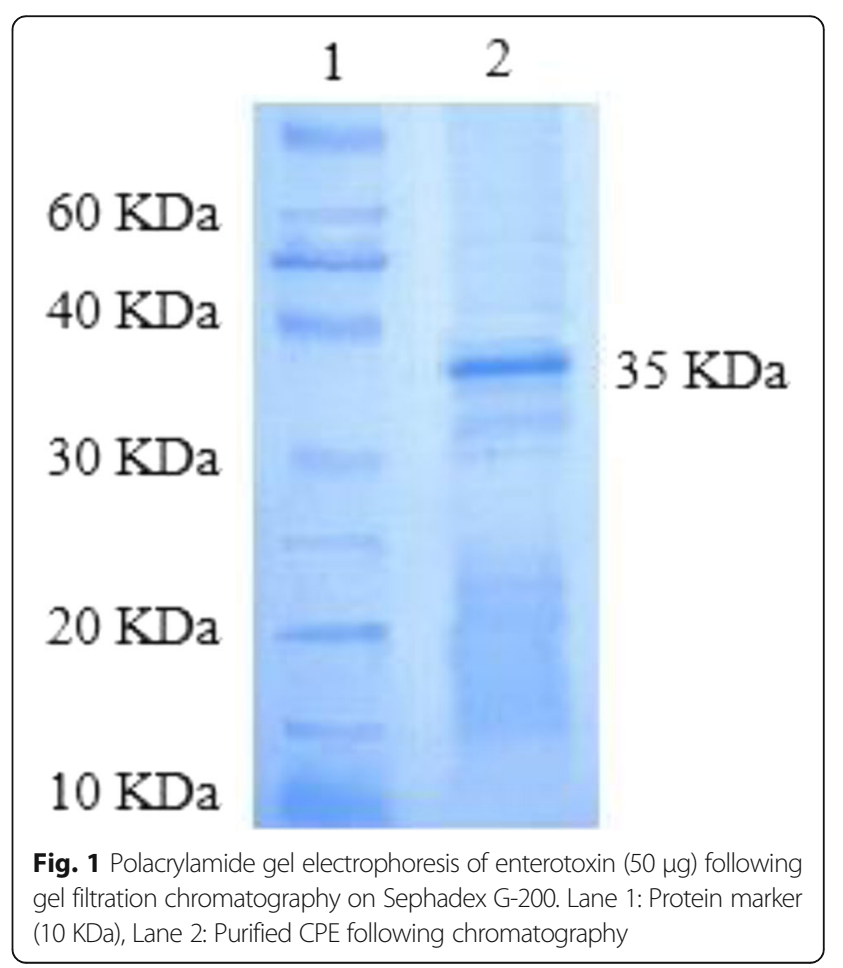




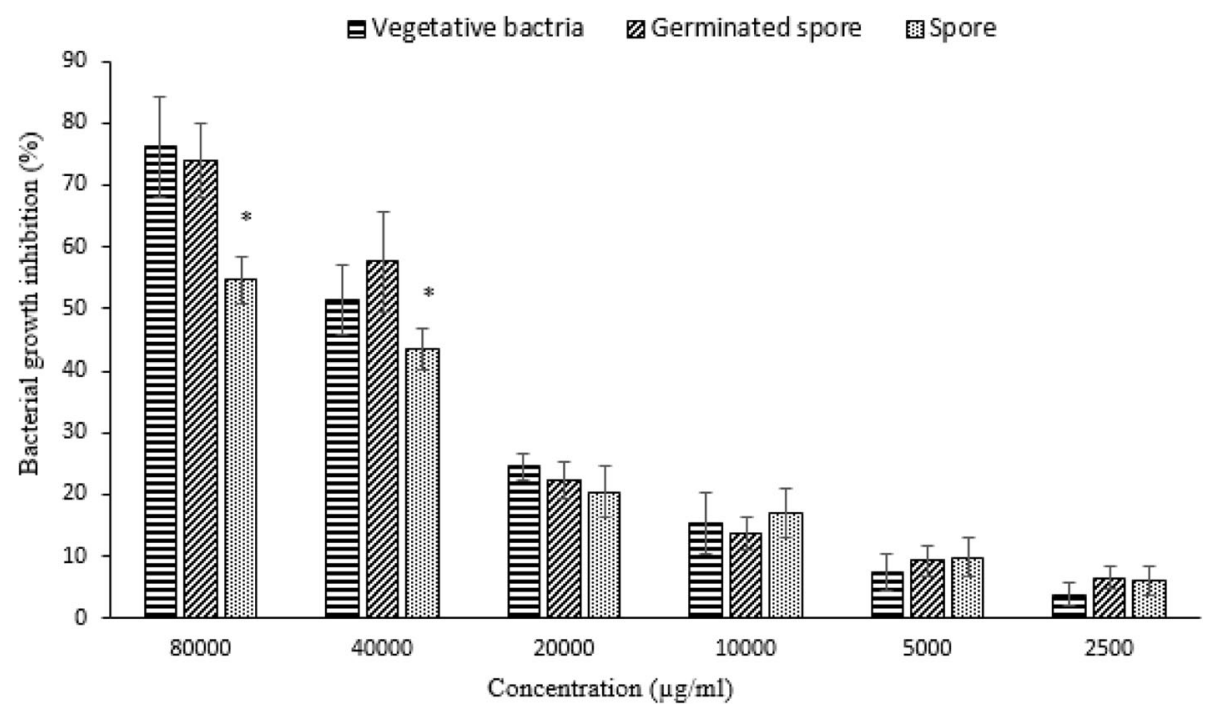

Fig. 2 Minimal inhibitory concentration (MIC) of crude antimicrobial substance (CAS) against vegetative, spore and germinated spore of $C$. perfringens type A. Bars represented SD values of triplicates. Symbol $\left(^{*}\right)$ on the bars of each concentration representing significant differences $(P<0.05)$

investigated on the Caco-2 monolayer using MTT assay. Details are given in Table 1. Caco- 2 cells treated with $4 \%$ CAS were least susceptible to cytotoxic effects, while cells treated with CPE $(1 \mu \mathrm{g} / \mathrm{mL})$, exhibited significantly higher cytotoxicity levels $(P<0.05)$. Details are given in Table 2. Due to the high cytotoxicity observed in $8 \%$ CAS, the treatment was not continued in subsequent experiments.

Table 1 Different experimental groups used in this study

\begin{tabular}{|c|c|}
\hline $\begin{array}{l}\text { Experimental } \\
\text { groups }\end{array}$ & Treatments \\
\hline 1 & Crude antimicrobial substance (CAS) 8\% \\
\hline 2 & CAS $4 \%$ \\
\hline 3 & B. subtilis ATCC 6633 \\
\hline 4 & Vegetative form of $C$. perfringens \\
\hline 5 & Spore form of $C$. perfringens \\
\hline 6 & Germinated spore form of $C$. perfringens \\
\hline 7 & C. perfringens enterotoxin (CPE) $(1 \mu \mathrm{g} / \mathrm{mL})$ \\
\hline 8 & CPE+ B. subtilis ATCC 6633 \\
\hline 9 & CPE + CAS 4\% \\
\hline 10 & $\begin{array}{l}\text { Vegetative form of C. perfringens }+ \text { B. subtilis } \\
\text { ATCC } 6633\end{array}$ \\
\hline 11 & Vegetative form of C. perfringens + CAS $4 \%$ \\
\hline 12 & Spore form of C. perfringens + B. subtilis ATCC 6633 \\
\hline 13 & Spore form of C. perfringens + CAS $4 \%$ \\
\hline 14 & $\begin{array}{l}\text { Germinated spore form of C. perfringens }+ \text { B. subtilis } \\
\text { ATCC } 6633\end{array}$ \\
\hline 15 & Germinated spore form of C. perfringens + CAS 4\% \\
\hline
\end{tabular}

Cytotoxic effects of co-cultured $B$. subtilis and $C$. perfringens on Caco- 2 cells

The effect of B. subtilis, CAS, different forms of $C$. perfringens and CPE on the Caco-2 cells was assessed, both independently and in a co-culture using the MTT assay (Table 3). The highest and lowest cell viability belonged to $4 \%$ CAS and CPE $(1 \mu \mathrm{g} / \mathrm{mL})$ groups, respectively $(P<0.05)$. Moreover, the survival rate of cells was increased in the combined groups compared with solitary positive groups (including CPE, spore, vegetative and germinated spore $)(P<0.05)$. Among co-cultured groups, the highest and lowest cell viability was found in groups 11 and 9 respectively. Generally, co-cultured B. subtilis and the pathogen showed higher cell viability compared to co-cultured CAS and the pathogen.

Table 2 Percent of the cytotoxicity of B. subtilis strains, crude antimicrobial substance (CAS) and different forms of $C$. perfringens in Caco-2 cells

\begin{tabular}{ll}
\hline Experimental groups & Cytotoxicity (\%) \\
\hline 1 & $32.09 \pm 1.84^{\mathrm{a}}$ \\
2 & $6.1425 \pm 0.82^{\mathrm{b}}$ \\
3 & $18.1375 \pm 1.36^{\mathrm{C}}$ \\
4 & $46.3675 \pm 1.52^{\mathrm{d}}$ \\
5 & $52.67 \pm 1.75^{\mathrm{e}}$ \\
6 & $65.0425 \pm 1.80^{\mathrm{f}}$ \\
7 & $94.9525 \pm 2.91^{\mathrm{g}}$ \\
\hline Values are mean SD of five replications. Different letters are represented the \\
statistical difference $(P<0.05)$. Treatments are described in Table 1.
\end{tabular}


Table 3 The survival rates (\%) of Caco-2 cells treated with various experimental groups using MTT and flow cytometry assays

\begin{tabular}{lll}
\hline Experimental & \multicolumn{2}{l}{ Cells survival (\%) } \\
\cline { 2 - 3 } groups & MTT assay & Flow cytometry assay \\
\hline Negative control & & $97.79 \pm 2.3^{\mathrm{a}}$ \\
2 & $95.16 \pm 3.59^{\mathrm{aA}}$ & $95.32 \pm 2.77^{\mathrm{bA}}$ \\
3 & $86.56 \pm 3.69^{\mathrm{bA}}$ & $92.71 \pm 2.77^{\mathrm{CB}}$ \\
4 & $56.02 \pm 1.8^{\mathrm{dA}}$ & $61.42 \pm 1.21^{\mathrm{eB}}$ \\
5 & $51.59 \pm 1.71^{\mathrm{eA}}$ & $57.65 \pm 0.83^{\mathrm{fB}}$ \\
6 & $37.66 \pm 2^{\mathrm{fA}}$ & $42.29 \pm 0.85^{\mathrm{gB}}$ \\
7 & $7.05 \pm 0.41^{\mathrm{CA}}$ & $13.08 \pm 0.71^{\mathrm{dB}}$ \\
8 & $12.74 \pm 0.73^{\mathrm{gA}}$ & $18.74 \pm 2.07^{\mathrm{hB}}$ \\
9 & $10.94 \pm 0.57^{\mathrm{gA}}$ & $16.32 \pm 1.1^{\mathrm{BB}}$ \\
10 & $65.55 \pm 1.75^{\mathrm{iA}}$ & $71.66 \pm 1.69^{\mathrm{kB}}$ \\
11 & $78 \pm 2.67^{\mathrm{kA}}$ & $85.42 \pm 0.87^{\mathrm{mB}}$ \\
12 & $59.85 \pm 2.58^{\mathrm{IA}}$ & $67.45 \pm 2.05^{\mathrm{nB}}$ \\
13 & $72.42 \pm 2.39^{\mathrm{jA}}$ & $78.33 \pm 1.89^{\mathrm{BB}}$ \\
14 & $44.83 \pm 1.67^{\mathrm{mA}}$ & $50.05 \pm 1.74^{\mathrm{OB}}$ \\
15 & $51.58 \pm 1.67^{\mathrm{e}}$ & $59.40 \pm 1.37^{\mathrm{a}}$ \\
\hline
\end{tabular}

Values are mean \pm SD of five and three replications for MTT and flow cytometry assays, respectively. Different small and capital letters are representing the statistical difference between each column and rows, respectively $(P<0.05)$. Treatments are described in Table 1.

\section{Survival rates, early apoptosis and necrosis of treated Caco-2 cells}

Survival rates, early apoptosis and necrosis of Caco-2 cells treated in whole groups was determined using a flow cytometry assay (Table 3 ). The highest cell viability belonged to the experimental group $2(95.32 \pm 2.77 \%)$ and the lowest to group $7(13.08 \pm 0.71 \%)(P<0.05)$. When the probiotic strain and CAS were used in combination, the highest and the lowest survival rates of the cells changed to groups 11 $(85.42 \pm 0.87 \%)$ and $9(16.32 \pm 1.1 \%)$. Caco- 2 cells treated with the co-cultured CAS and the pathogen revealed higher survival rates, in which, the most cell viability belonged to the experimental groups 11 (85.42 $\pm 0.87 \%)$, $13(78.33 \pm 1.89 \%)$ and 15 (59.40 $\pm 1.37 \%)$.

As shown in Fig. 3, the highest rate of apoptosis was recorded in the group $7(79.83 \pm 2.96 \%)$ and $9(71.84 \pm 3.87 \%)$ and the highest rate of necrosis belonged to the group 6 (30.6 $\pm 0.9 \%)$. However, the lowest apoptotic rate was found in the group number $2(2.83 \pm 0.8 \%)$. The lowest rate of necrosis was shown in the group number $2(1.85 \pm 0.52)$ and 3 $(2.33 \pm 0.56)(P<0.05)$. In general, apoptosis rate was significantly higher or equal to the rate of necrosis in all the groups except groups 6,12 and 14 in which, a diverse range has been observed $(P<0.05)$.

\section{Discussion}

Our results showed B. subtilis bacteriocin-containing antimicrobial substance was effective against the growth of vegetative bacterium, germinated spore and spore of $C$. perfringens, with vegetative cells and germinated spores most affected in MIC assay. Due to the lower MIC required for inhibition of vegetative $C$. perfringens and the considerably high numbers of spores identified by selective staining compared with vegetative forms, this was probably the result of delayed germination of spores [21]. Ávila et al. (2013), found that the vegetative forms of Clostridium species exhibit higher sensitivity to ruterin and nisin than spore forms. Our result was consistent with previous reports demonstrating the inhibitory activities of nisin and partially purified bacteriocin extracted from lactic acid bacteria on the vegetative forms of Clostridia spp. [22, 23]. According to previous reports, lantibiotic peptides containing subtilin and subtilosin A produced by B. subtilis ATCC 6633, were able to inactivate numerous Gram negative and especially Gram-positive bacteria by forming voltagedependent pores in bacterial cytoplasmic membranes [24]. Moreover, protease and pronase enzymes produced by $B$. subtilis are known to inhibit the function of CPE [25], and such proteolytic enzymes are likely present in our extract. Furthermore, it seems that a nonspecific mechanism of steric hindrance of probiotics blocks adherence of pathogens to their cell mediated receptors which is likely to be the case for $\mathrm{CPE}[7,26]$. One previous study implied that PB6, PB3 and ATCC 6633 strains of B. subtilis secrete anti-clostridial factors against $C$. perfringens, a causative agent of poultry necrotic enteritis, using well diffusion assay [27]. It was also found that LFB112 and 8A strains of $B$. subtilis isolated from plants and soil have inhibitory effects against $C$. perfringens via production of bacteriocin [28]. Generally, the majority of vegetative forms of $C$. perfringens strains have exhibited higher sensitivity to nisin, (a bacteriocin which is structurally and functionally similar to lantibiotic produced by B. subtilis ATCC 6633) than spores [29-31].

We also evaluated the cytotoxicity levels of CAS (4\%, $8 \%)$, B. subtilis, enterotoxin and different forms of $C$. perfringens. Our findings showed that $4 \%$ CAS had the lowest cytotoxic percentage, and CPE the highest. 8\% CAS also demonstrated high cytotoxicity, probably due to high levels of toxic components such as proteins in the culture medium. Our results are consistent with those of several former studies [18, 32, 33]. CPE synthesis is not only dependent on bacterial sporulation, but also can be released by spore disruption [34]. As such, the toxin can be released by spore germination. Our results revealed higher cell toxicity by the germinated spore form of C. perfringens compared to spore and vegetative bacteria. In agreement with earlier studies, exposing CPE $(1 \mu \mathrm{g} / \mathrm{mL})$ to Caco- 2 and Vero cells for $15 \mathrm{~min}$ induced $40 \%$ and $90 \%$ of cell death, respectively. In addition, $1 \mu \mathrm{g}$ of $\mathrm{CPE} / \mathrm{mL}$ was able to induce clear morphological damage within $60 \mathrm{~min}$, followed by $95 \%$ death, in Caco- 2 


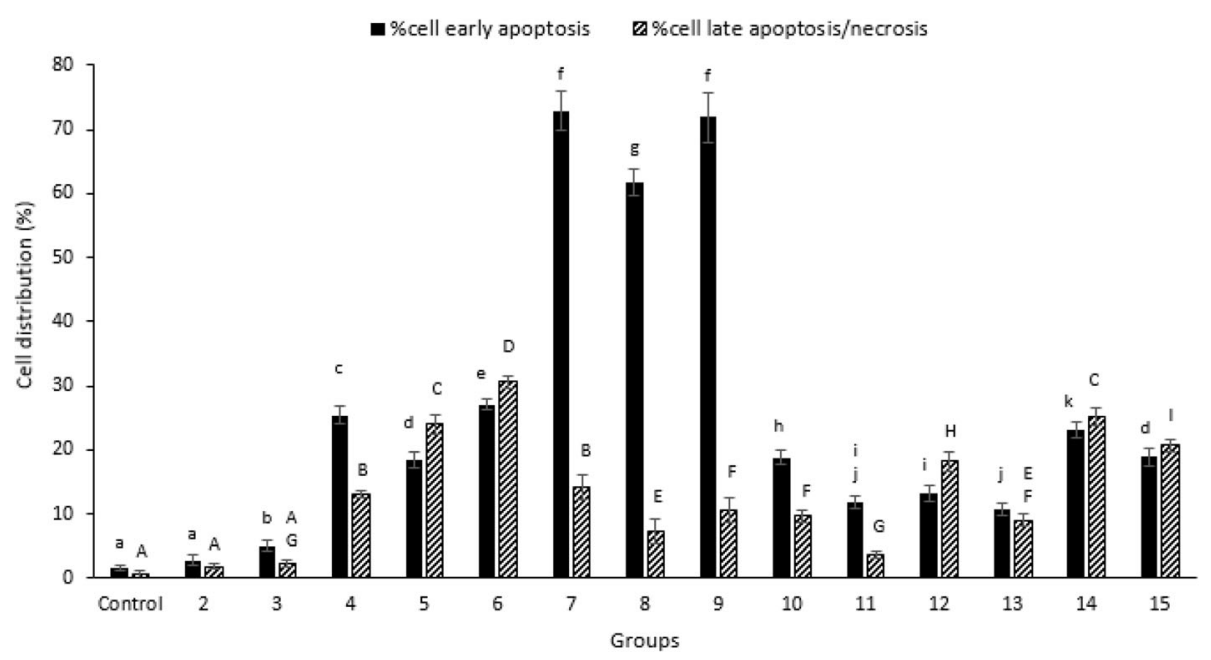

Fig. 3 Percent of apoptotic and necrotic effects on the Caco-2 cells treated with B. subtilis ATCC 6633 or PY79 stains and different forms of C. perfringens using flow cytometry assay. Bars represented SD values of triplicates. Different small and capital letters on the bars, representing significant differences for apoptotic and necrotic cells, respectively $(P<0.05)$. Groups are described in Table 1

cells $[35,36]$. The ability of spore and vegetative forms of C. perfringens to adhere to intestinal epithelial cells was a likely avenue to causing cell damage [37]. Furthermore, our results clarified that the co-culture of probiotics or CAS and different forms of C. perfringens, had lower cytotoxic effects than the pathogen, using both assays. CAS which contains subtilin, subtilosin A and bacteriocin-like inhibitory substances, potentially affects the spore and vegetative forms of $C$. perfringens, suggesting the release of CPE during spore vegetation [38].

Flow cytometry was employed to further investigate the process of apoptosis and necrosis in the affected cells. Since some of the viable cells may detach from the bottom of the microplate wells during washing stage of MTT assay, the OD was frequently lower than the control group. Hence, in the majority of our experimental groups, the survival rates of Caco-2 cells were significantly higher using flow cytometry $(P<0.05)$.

Although the viability obtained from MTT and flow cytometry assays were similar, the MTT method seems to be more effective for bacterial metabolites [18, 32, 39, 40]. Due to sustained bacterial attachment, even after several washes, the OD of the remaining cells was higher following absorption of MTT stain.

Not surprisingly, the highest rate of apoptosis was demonstrated in the toxin and toxin plus CAS groups as formerly investigated $[14,41]$. In general, apoptosis and necrosis in co-cultured groups were significantly lower than positive control groups $(P<0.05)$ which alludes to the beneficial effects of $B$. subtilis and its antimicrobial substance. The rate of cell necrosis and apoptosis in spore and germinated spore groups was higher than the vegetative forms which was most likely due to their higher tendency to adhere to Caco-2 cells [20,37].

\section{Conclusions}

This study suggested that $B$. subtilis probiotic was effective against various forms of $C$. perfringens type A in Caco-2 cell culture via antimicrobial substances. Further, we showed that the majority of treatments had higher cell viability in flow cytometry compared with the MTT assay due to higher specificity and for monitoring cell death.

However, although in vitro models are able to mimic the humans' GI tracts, complimentary in vivo validation is also necessary.

\section{Additional files}

Additional file 1: Chromatography of CPE. (DOC $106 \mathrm{~kb}$ )

Additional file 2: CPE concentration using Bradford assay. (DOC 35 kb)

Additional file 3: MIC of CAS. (DOC $40 \mathrm{~kb}$ )

Additional file 4: Percent of cytotoxicity (MTT assay). (DOC $32 \mathrm{~kb}$ )

Additional file 5: Percent of cell viability (MTT assay). (DOC $37 \mathrm{~kb}$ )

Additional file 6: Flow cytometry. (DOC $51 \mathrm{~kb}$ )

\section{Abbreviations}

CAS: Crude antimicrobial substance; CPE: Clostridium perfringens enterotoxin; DW: Distilled water; MIC: Minimal inhibitory concentration; MTT: 3-(4,5 dimethylthiazol-2-yl)-2,5-diphenyl tetrazolium bromide

\section{Acknowledgements}

Authors wish to thank the staff at Department of Food Hygiene and Public Health, in particular Dr. Derakhshandeh and Mr. Mahboobi at the Central Laboratory for their invaluable support. The work was kindly supported by Shiraz University, Shiraz, Iran.

\section{Funding}

The current study was financially supported by School of Veterinary Medicine, Shiraz University which is gratefully acknowledged. The funder had no role in the design, collection of samples, analysis, interpretation or writing of the manuscript.

Availability of data and materials

All raw data are provided in the Additional files 1, 2, 3, 4, 5 and 6 . 


\section{Authors' contributions}

This research was part of the PhD project. MP performed the laboratory work and wrote the draft of manuscript. SH was the first supervisor to this project, designed the study and revised the manuscript. SSS was the co-supervisor of the project, participated in coordination, revised the manuscript and also participated in the statistical analysis; TK was the advisor of the PhD project, and carried out the flow cytometry analysis. All authors read and approved the final manuscript.

\section{Competing interests}

The authors declare that they have no competing interests.

\section{Consent for publication}

Not applicable.

Ethics approval and consent to participate

Not applicable.

\section{Publisher's Note}

Springer Nature remains neutral with regard to jurisdictional claims in published maps and institutional affiliations.

\section{Author details}

'Department of Food Hygiene and Public Health, School of Veterinary Medicine, Shiraz University, P.O. Box: 71441-69155, Shiraz, Iran. ²Diagnostic Laboratory Sciences and Technology Research Center, School of Paramedical Sciences, Shiraz University of Medical Sciences, Shiraz, Iran.

Received: 11 January 2017 Accepted: 16 June 2017

Published online: 04 July 2017

\section{References}

1. McClane BA, Chakrabarti G. New insights into the cytotoxic mechanisms of Clostridium perfringens enterotoxin. Anaerobe. 2004;10(2):107-14.

2. Fioramonti J, Theodorou V, Bueno L. Probiotics: what are they? What are their effects on gut physiology? Best Pract Res Cl Ga. 2003;17(5):711-24.

3. Sanders ME: Probiotics: definition, sources, selection, and uses. Clin Infect Dis. 2008;46(Supplement 2):S58-S61.

4. Sorokulova IB, Pinchuk IV, Denayrolles M, Osipova IG, Huang JM, Cutting SM, et al. The safety of two Bacillus probiotic strains for human use. Dig Dis Sci. 2008;53(4):954-63.

5. Cutting SM. Bacillus probiotics. Food Microbiol. 2011;28(2):214-20.

6. Huang J-M, La Ragione RM, Nunez A, Cutting SM. Immunostimulatory activity of Bacillus spores. FEMS Immunol Med Microbiol. 2008:53(2):195-203.

7. Ye X, Li P, Yu Q, Yang Q. Bacillus subtilis inhibition of enterotoxic Escherichia coli-induced activation of MAPK signaling pathways in Caco-2 cells. Ann Microbiol. 2013;63(2):577-81.

8. La Ragione RM, Casula G, Cutting SM, Woodward MJ. Bacillus subtilis spores competitively exclude Escherichia coli O78: K80 in poultry. Vet Microbiol. 2001;79(2):133-42.

9. La Ragione RM, Woodward MJ. Competitive exclusion by Bacillus subtilis spores of Salmonella enterica serotype Enteritidis and Clostridium perfringens in young chickens. Vet Microbiol. 2003;94(3):245-56.

10. Dunne C, O'Mahony L, Murphy L, Thornton G, Morrissey D, O'Halloran S, Feeney M, Flynn S, Fitzgerald G, Daly C: In vitro selection criteria for probiotic bacteria of human origin: correlation with in vivo findings. Am J Clin Nutr. 2001;73(2):386s-392s

11. Paredes-Sabja D, Torres JA, Setlow P, Sarker MR. Clostridium perfringens Spore germination: characterization of germinants and their receptors. J Bacteriol. 2008;190(4):1190-201.

12. McDonel JL, McClane BA. Production, purification, and assay of Clostridium perfringens enterotoxin. Method enzymol. 1987;165:94-103.

13. Heredia NL, Garcia-Alvarado J, Labbé RG. Improved rapid method for production and purification of Clostridium perfringens type a enterotoxin. J Microbiol Methods. 1994;20(2):87-91.

14. Chakrabarti G, McClane BA. The importance of calcium influx, calpain and calmodulin for the activation of $\mathrm{CaCo}-2$ cell death pathways by Clostridium perfringens enterotoxin. Cell Microbiol. 2005;7(1):129-46.

15. Bradford MM. A rapid and sensitive method for the quantitation of microgram quantities of protein utilizing the principle of protein-dye binding. Anal Biochem. 1976;72(1-2):248-54.
16. Casey J, O'Cleirigh C, Walsh P, O'Shea D. Development of a robust microtiter plate-based assay method for assessment of bioactivity. J Microbiol Methods. 2004;58(3):327-34

17. Thirabunyanon $\mathrm{M}$, Thongwittaya N. Protection activity of a novel probiotic strain of Bacillus subtilis against Salmonella Enteritidis infection. Res Vet Sci. 2012:93(1):74-81.

18. Ozkan AD, Han D, Umu OC, Angun P, Senturk B, Yasa O, et al. Screening and selection of novel animal probiotics isolated from bovine chyme. Ann Microbiol. 2013;63(4):1291-300.

19. Allaart JG, van Asten AJ, Vernooij JC, Gröne A. Effect of Lactobacillus fermentum on beta2 toxin production by Clostridium perfringens. Appl Environ Microbiol. 2011;77(13):4406-11.

20. Grootaert C, Boon N, Zeka F, Vanhoecke B, Bracke M, Verstraete W, et al. Adherence and viability of intestinal bacteria to differentiated Caco-2 cells quantified by flow cytometry. J Microbiol Methods. 2011:86(1):33-41.

21. Abriouel H, Maqueda M, Gálvez A, Martínez-Bueno M, Valdivia E. Inhibition of bacterial growth, enterotoxin production, and spore outgrowth in strains of Bacillus cereus by bacteriocin AS-48. Appl Environ Microbiol. 2002;68(3):1473-7.

22. Meghrous J, Lacroix C, Simard R. The effects on vegetative cells and spores of three bacteriocins from lactic acid bacteria. Food Microbiol. 1999;16(2):105-14.

23. Ávila M, Gómez-Torres N, Hernández M, Garde S. Inhibitory activity of reuterin, nisin, lysozyme and nitrite against vegetative cells and spores of dairy-related Clostridium species. Int J Food Microbiol. 2014;172:70-5.

24. Shelburne CE, An FY, Dholpe V, Ramamoorthy A, Lopatin DE, Lantz MS. The spectrum of antimicrobial activity of the bacteriocin subtilosin a. J Antimicrob Chemother. 2007;59(2):297-300.

25. Foods ICoMSf: Microorganisms in Foods 5: Characteristics of Microbial Pathogens, vol. 5: Springer Science \& Business Media; 1996.

26. Tsai C-C, Hsih H-Y, Chiu H-H, Lai Y-Y, Liu J-H, Yu B, et al. Antagonistic activity against Salmonella infection in vitro and in vivo for two Lactobacillus strains from swine and poultry. Int J Food Microbiol. 2005;102(2):185-94.

27. Teo AY-L, Tan H-M. Inhibition of Clostridium perfringens by a novel strain of Bacillus subtilis isolated from the gastrointestinal tracts of healthy chickens. Appl Environ Microbiol. 2005:71(8):4185-90.

28. Xie J, Zhang R, Shang C, Guo Y. Isolation and characterization of a bacteriocin produced by an isolated Bacillus subtilis LFB112 that exhibits antimicrobial activity against domestic animal pathogens. Afr J Biotechnol. 2009:8(20): 5611-19.

29. Parisot J, Carey S, Breukink E, Chan WC, Narbad A, Bonev B: Molecular mechanism of target recognition by sabtilin, a class I lanthionine. Antimicrob Agents Chemother. 2008; 52 (2): 612-618.

30. Baruzzi F, Quintieri L. Morea M. Caputo L: Antimicrobial compounds produced by Bacillus spp and applications in food Science against microbial pathogens: commun Current Res Technol Adv. 2011;2:1102-11.

31. Garde S, Gómez-Torres N, Hernández M, Ávila M. Susceptibility of Clostridium perfringens to antimicrobials produced by lactic acid bacteria: Reuterin and nisin. Food Control. 2014:44:22-5.

32. Hong H, Huang JM, Khaneja R, Hiep L, Urdaci M, Cutting S. The safety of Bacillus subtilis and Bacillus indicus as food probiotics. J Appl Microbiol. 2008;105(2):510-20

33. Rowan NJ, Deans K, Anderson JG, Gemmell CG, Hunter IS, Chaithong T. Putative virulence factor expression by clinical and food isolates of Bacillus spp. after growth in reconstituted infant milk formulae. Appl Environ Microbiol. 2001;67(9):3873-81.

34. Cavalcanti MTH, Porto T, Porto ALF, Brandi IV. Lima Filho JLd, Pessoa junior a: large scale purification of Clostridium perfringens toxins: a review. Rev Bras Cienc Farm. 2004;40(2):151-64

35. Chakrabarti G, Zhou X, McClane BA. Death pathways activated in CaCo-2 cells by Clostridium perfringens enterotoxin. Infect Immun. 2003;71(8):4260-70.

36. Singh U, Mitic LL, Wieckowski EU, Anderson JM, McClane BA. Comparative biochemical and immunocytochemical studies reveal differences in the effects of Clostridium perfringens enterotoxin on polarized CaCo-2 cells versus Vero cells. J Biol Chem. 2001;276(36):33402-12.

37. Jiang Y, Kong Q, Roland KL, Wolf A, Curtiss R. Multiple effects of Escherichia coli Nissle 1917 on growth, biofilm formation, and inflammation cytokines profile of Clostridium perfringens type a strain CP4. Pathog Dis. 2014;70(3):390-400.

38. Ryu S, Labbe RG. Coat and enterotoxin-related proteins in Clostridium perfringens spores. Microbiol. 1989:135(11):3109-18.

39. Thirabunyanon M, Boonprasom P, Niamsup P. Probiotic potential of lactic acid bacteria isolated from fermented dairy milks on antiproliferation of colon cancer cells. Biotechnol Lett. 2009;31(4):571-6. 
40. Wang X, Xia Y, Liu L, Liu M, Gu N, Guang H, et al. Comparison of MTT assay, flow cytometry, and RT-PCR in the evaluation of cytotoxicity of five prosthodontic materials. J Biomed Mater Res B Appl Biomater. 2010;95(2):357-64.

41. Ferrarezi MC, Curci VC, Cardoso TC. Cellular vacuolation and mitochondrialassociated factors induced by Clostridium perfringens Epsilon toxin detected using acoustic flow cytometry. Anaerobe. 2013;24:55-9.

Submit your next manuscript to BioMed Central and we will help you at every step:

- We accept pre-submission inquiries

- Our selector tool helps you to find the most relevant journal

- We provide round the clock customer support

- Convenient online submission

- Thorough peer review

- Inclusion in PubMed and all major indexing services

- Maximum visibility for your research

Submit your manuscript at www.biomedcentral.com/submit 